\title{
The Problem of Textual (Ir)Relevance in Byron's Don Juan: A Critique of Editorial Procedure
}

Asha Varadharajan

Textual critics and producers of critical editions of 'canonical' texts seem confronted with a problem that may be described as a version of Stanley Fish's 'is there a text in this class?' This paper attempts to raise the issues pertinent to this problem through a consideration of two major critical editions of the text of Byron's Don Juan - T.G. Steffan and W.W. Pratt's Byron's Don Juan: A Variorum Edition (4 vols.) ${ }^{1}$ and Jerome J. McGann's Lord Byron: The Complete Poetical Works (vol.5). ${ }^{2}$ I should perhaps clarify that my interest is in the editorial principles which inform these editions rather than in an enumeration of the specifics of editorial practice. This is, as I. hope to demonstrate, a precarious distinction, but a necessary one in order to articulate my difference in emphasis.

My choice of Byron's Don Juan is less than innocent. The desire to defer to authorial presence (in terms of his 'final intentions') acquires interesting dimensions in the context of the battle Byron waged between anonymity and personality, and the discursive representation of that struggle both in the evolution of his text and in editorial practice that claims access to authorial sanction.

Before I consider editorial precept and practice in relation specifically to editions of Don Juan, I wish to attempt a brief historical survey of the rationale that informs my choice of copy-text and the processes of editing and textual criticism. My effort is not so much to make an original contribution to this debate as to declare my own allegiances and to offer a context for the critique which follows these provisional contentions.

The pre-eminence of W. W. Greg's 'rationale of copy-text' resulted in a heroic quest for an impossible ideal - the simultaneously irretrievable and incorruptible original text. The job of the textual critic entailed a retracing of the dissemination of the text in question, carefully restoring it to its

Asha Varadharajan teaches Critical Theory in the Department of English, Memorial University, St. John's, Newfoundland. She is currently completing a Ph.D. at the University of Saskatchewan. 
original pristine state by peeling away layers of corruption (scribal and printing errors) and of overdetermination. Greg's theory became possible only because many of the texts of Renaissance drama were lost and extant manuscripts were the products of diverse hands. In other words, it was the impossibility of being a purist that produced Greg's version of textual authority, a version that rapidly became confused with authorial intention. Greg is not entirely to blame in this regard, of course; he would probably rely on extant versions of texts rather than on editorial fictions of authorial sanction.

This confusion becomes evident in the theorizing of Fredson Bowers, ${ }^{3}$ whose concern is mainly with nineteenth-century American fiction. Bowers had access to the original manuscripts of much of Hawthorne's fiction, and chose to advocate their textual authority over that of the first editions, because the accidentals in the latter did not correspond with those of the manuscript. This, however, constituted a misuse of the substantives / accidentals distinction, as I shall go on to explain.

Greg's controversial distinction between substantives and accidentals was an attempt to free the critic / editor from 'the tyranny of the copy-text' in order that an 'eclectic' text might be produced that relied on critical judgement as well as the textual evidence in question. Greg would not, I believe, have envisaged the 'eclectic' text as an invitation to bowdlerize; rather he acknowledged the inevitably subjective dimension of editorial practice and textual criticism. After all, the collation and sifting of evidence does not occur independently of human agency.

For Bowers, ${ }^{4}$ authority is much less relative than it is for Greg - the possession of the manuscript becomes the occasion of a rationale of copy-text that fails to distinguish between manuscript and edition, or that sees the latter as intervention in and as corruption of idiosyncratic genius. In short, Bowers does not account for the institutions of literary production that transform a manuscript into a text.

Moreover, authorship is a far more collaborative effort than Bowers is willing to admit. Editorial intervention is often solicited or just assumed by the author in question. I do not wish to discount Bowers's contribution to the theory of editorial procedure; rather, I wish to emphasize that his notions are based on a genealogical version of textual dissemination / corruption and on a version of intellectual property that sees texts as engendered by their authors, as springing full-blown from the heads of these aspiring Zeuses. Midwifery is, of course, the controlling metaphor of authorial pretension / production!

G. Thomas Tanselle ${ }^{5}$ sees the distinction between accidentals and substantives as a necessary if artificial distinction for pragmatic purposes. $\mathrm{He}$ offers an interesting resolution to the problem of the authority of extant 
manuscripts, however, by making a crucial distinction between those intended for publication and those characterized as private documents. In the case of the latter, he argues, a rigid adherence to the minutiae of accidentals is crucial because they are read precisely as flavourful accounts of personality and historical period, as redolent of 'felt life.' Form and content, therefore, become inextricable.

The kinds of instability introduced in the process of developing a rationale for editorial concerns seem familiar in the context of contemporary literary theory's dismantling of fictions of self, authority, and (definitive) text, and suggest possibilities for both the reading of texts and the sifting and collating of textual evidence. In fairness to Bowers, negotiating this territory is at best a daunting task. The attempt to undermine notions of spontaneous, creative genius and to emphasize the collaborative production and revision of a text is not always readily distinguishable from deliberate authorial craft and intention.

Morse Peckham ${ }^{6}$ raises many of these issues, for the most part persuasively, despite his rather forbidding 'scientific' tone. The editor of a critical text, according to Peckham, does not so much retrieve a text which represents its author's final intentions as construct or postulate a version of a text that is always already a version - a product of an author's cultural and semiotic situation. Peckham wishes to rescue editorial practice from its proclivity for 'the language of hagiology, ${ }^{\prime 7}$ its penchant for sacred texts and authorial monads.

While Peckham's indication of the ideological and institutional constraints on literary production or the effects of 'policing ${ }^{\prime 8}$ as he calls them, are salutary, his theory contradicts itself on at least two counts. If the textual editor's 'problem is empirical [and] cannot be solved a priori, ${ }^{\prime 9}$ is Peckham not guilty of privileging the 'printed artifact' 10 as a reflection of human behaviour, its material inscription as it were, that is nevertheless readable only through the mediation of the 'categorical conventions of the critic's own cultural situation?' ${ }^{11}$ In a curious fashion, text and critic are exempt from the constraints of a cultural and semiotic situation that pertains solely to the author. Besides, by rendering the text valuable only in so far as it makes past human behaviour accessible, Peckham has let the author in through the back door. The study of a text in process, or the synthesizing of multiple versions of a postulated text could very easily become an excuse for an inquiry into poetic behaviour or a construction of poetic personality. Peckham's recognition that poetic behaviour remains a construct inextricable from its textual and historical context, however, renders his account rather more practicable than those that reside in the spontaneous overflow of powerful feeling.

Alan Liu's review of David Simpson's text, Wordsworth's Historical 
Imagination: The Poetry of Displacement suggests a view of Romantic selfhood that might very well serve as a paradigm for textual criticism that simultaneously alters the reading of a text. Liu does not offer it as such; however, his conception of the "self" as the register of a dynamic becoming of social responsiveness ${ }^{\prime 12}$ avoids the pitfalls of Peckham's formulation. Peckham's negotiation of the traffic between text and context has the effect of bracketing the author who mediates that traffic, leaving no room for human determination.

As far as the textual critic or editor is concerned, to recapitulate my observations, Peckham's argument in effect occupies both sides of a problematic issue. He seems effectively to have eliminated the challenge of romantic genius, but succeeds in resurrecting the author by making the text the just reflection of poetic personality. Besides, Peckham chooses to characterize author and text merely as passive products of a cultural and semiotic situation when they are also active responses to that situation. Finally, the editorial procedure in these terms also brackets the critic, who is transformed into a 'medium' for the transmission of an empirical phenomenon - the text.

Just as substantives are meaningless without accidentals, textual editing as an empirical phenomenon is useless without a historical, theoretical and ideological basis. In short, the process is always and inevitably a combination of empirical analysis and eclectic synthesis. It is this version of editorial procedure that seems to me implicit in Liu's plea for theorized particulars - the mere accumulation of detail serves little purpose. It is also crucial to the production of editions such as Steffan and Pratt's and McGann's where the distinctions between material evidence and authorial intention, between poetry and autobiography, between interest in the genesis of poetic product and interest in the genesis of poetic personality, and between significant context and topical detail become progressively complicated and blurred.

Donald Reiman describes the desire of editors of Romantic texts 'to present "relatively rough and unpolished texts" that "reflect the vagaries of authorial behavior, rather than a regularized, polished redaction reflecting an editor's idealized conception of an author's intention"..13 The emphasis is on presenting 'the historical reality of the author's text, ${ }^{14}$ a task made relatively feasible by the vast quantity of material evidence and even of explicit statements of authorial intention. The Cornell Wordsworth, for instance, offers a text-in-process: transcriptions of manuscripts together with photographic reproductions, and a reading text from which revisions and variants have been removed.

The emphasis on historical reality might undergo some modification in relation to the type of reader for which the critical text is intended. The 
effort to produce a reliable text need not require the appending of vast quantities of editorial apparatus. One has only to recall the reviewers' complaints about the price of McGann's edition to realize the importance of the audience of a particular critical edition. Also, the distinction between holographs designed for publication and those written for private circulation becomes crucial. Fidelity to original manuscripts cannot afford to ignore the explicit rejection of sections of texts, regardless of the reasons for such rejection. Reiman rightly argues against the 'vanity of superior hindsight ${ }^{\prime 15}$ in this regard.

The adherence to authorial intention here is dependent on written evidence and is to be contrasted with fidelity to a romantic conception of authorial or textual integrity. Authorial intention, McGann contends, is incomplete without the conjunction of text and reader and even before a text reaches its audience, its 'creation' is contingent upon 'the conventions and enabling limits that are accepted by the prevailing institutions of literary production. ${ }^{16}$ The textual editor, in McGann's terms, reproduces the history of the text by recording the translation of the creative process into a social product and by discriminating between versions of a text. The latter process is not so much an attempt to recover a text through the elimination of its corruptions as a determination of the relations between versions, all of which contribute to the reconstructed text.

The Variorum edition of Don Juan precedes McGann's and is interesting from several points of view. T.G. Steffan, one of the editors, writes of the inception of the edition as primarily an 'interpretive monograph about Byron's mind and art at work on the composition of Don Juan. ${ }^{17}$ Steffan's intention seems to have been to provide a biographical context for the poem that would detail the circumstances of composition. Interestingly, however, Steffan moves into unabashedly speculative territory: 'from the graphic evidence of [Byron's] additions, rejections, deletions, and substitutions [Steffan argues], much can be deduced about his creative process, the workings of a vigorous mind, the pressures of his turbulent personality, and the methods of his deliberate artistry. ${ }^{18}$

Editorial practice becomes the occasion for a cult of personality that deploys graphic evidence in the interests of a psychological account of the motivating factors that produced the poem. Vol. I is devoted to a detailed account of Byron's revisions and expurgations that focuses on the exigencies of time, place and temperament rather than on the editorial process of producing a reliable text. Textual authority is of course implicit in the very recreation of the false starts that became Byron's epic, but the interest seems to lie in explication of the poem and in explaining away its difficulties.

How is one to distinguish between this version of a text-in-process and 
McGann's reconstitution of the 'definitive' versions of Byron's works? McGann's concerns are forthrightly textual - his edition has been called for by the discovery of poems that would expand Byron's corpus and, ironically, by the discovery of evidence that would prove much of the extant corpus corrupt. As far as Don Juan is concerned, new 'rejected' stanzas have become available. The Variorum edition does not utilize Byron's corrected proofs, and therefore multiplies the errors of earlier editions that have suffered in the transcription. The emphasis, in short, shifts from resurrecting the author to reproducing the text as physical object, from questions of authorial intention to those of textual relevance, and from the purity of text to the relations of textual production. I should like to return to specific aspects of both editions in an attempt to qualify my contentions and to speculate on the implications of the choices made by the editors in question. My own position is somewhere in the middle and symptomatic of a common dilemma - every editorial / textual precept necessarily modifies itself in practice and can be held only with reservations. However, as Greg realized, the inevitability of error ensures the value of subsequent efforts.

Reiman's call for editors to reproduce 'his [the author's] poem - not ours $^{\prime 19}$ becomes problematic when confronted with the Variorum edition of Don Juan. Reiman's concern for the exercise of historicist principles makes possible his privileging of the 'editorial process over contextual historical research' ${ }^{20}$ in other words, the editorial attempt to establish a text must confine itself to the facts of the case, to the rather large body of manuscripts, holographs, proofs and printer's copies that support its argument for textual relevance.

The problem, however, with relying on available evidence is that the relations of literary production are rarely limited, as Reiman seems to think, to the collation and interrelation of all textual evidence such that all variants are recorded and accidentals stabilized. Reiman wishes to suggest a difference in emphasis, of course, but his argument could bear some qualification from Liu and Peckham and some illustration and complication from the principles which inform the Variorum edition.

Despite what might strike one as the elimination of the human factor in Reiman's argument, his claims for editorial process are inevitably linked to the recording of 'the vagaries of authorial behavior.' The texts of the documents become instrumental in this regard, because they reproduce 'the original source in its strangeness ${ }^{21}$ without editorial intrusions that might seek to stabilize inconsistency and embellish roughness.

Such an aim, at least, distinguishes the Variorum edition. It records a 'chronicle' of poetic composition through 'an all-inclusive transcription of the manuscript variants.... ${ }^{\prime 22}$ The historicist principle operates here in the 
choice of copy-text. The first edition's 'very violation of uniformity is cousin to the natural and haphazard inconsistency of the manuscripts ${ }^{23}$ and can claim historical priority. Is the distinction then to be made between the reproduction / reflection of final authorial intention and its painstaking reconstruction? As Peckham argues and the Steffan-Pratt edition demonstrates, reproduction is not possible without reconstruction and even the best of editions can only offer a postulate, not a reflection, of final authorial intention.

Several statements in Vol. I and in the delineation of editorial practice make one decidedly uneasy regarding the neutral recording of poetic behaviour. The editors confess to inconsistency in editorial process particularly in relation to what is described as Byron's 'whimsical punctuation or capitalization ${ }^{24}$ with simultaneous insistence on minute accuracy. While the editors choose not to modernize spellings in deference to Byron's wishes, they do alter capitalization, italics, and terminal verse punctuation when Byron's practice seems unjustifiable. Even orthography bears modification if the contemporary reader is in danger of misunderstanding. The nature of the reader of this edition shifts from the scholarly to the common without justification.

The attempt to turn the edition into a 'chronicle ${ }^{\prime 25}$ parallels the attempt to 'reduce' the manuscripts to 'intelligible order, ${ }^{26}$ to accord them a sequence of composition, and to afford them continuity - all in the interests of clarity. The emphasis is on a compilation of biographical detail apposite to the circumstances of composition and on a desire to construct life and text as parallel and interactive histories. Byron's volubility renders the editors' desire feasible because his letters and marginalia survive as clues to the indefatigable researcher of his version of T.S. Eliot's 'the man who suffers and the mind which creates.'

In short, Peckham's contention that there may not after all be a text to be retrieved seems pertinent in the context of an apparently objective procedure that constantly requires the exercise of judgement. Steffan and Pratt are particularly disarming, however, in that they 'fess up' to their pretensions and prejudices even if they are relatively sanguine about silent emendations.

Since a whole volume is devoted to an expository and critical purpose, the Variorum edition might be seen to combine the skills of literary and textual critic in order to produce a text of Don Juan that also revises conceptions of Byron and interpretation of his poem. Steffan is aware of the dangers of focusing on revisions / deletions that belie the (dis)continuities of composition, but is less shy of the speculative than a textual critic might be, because he interprets manuscript revisions in light of certain thematic foci in the poem. 
More problematically, Steffan believes the 'focus of revision is an empirical index to the qualities of [Byron's] genius and temperament ${ }^{\prime 27}-\mathrm{a}$ position, interestingly enough, not unlike Peckham's for all the latter's post-structuralist claims. Steffan seems torn between a version of Byron as naturally given to excess (the popular myth of erratic genius) and one which interprets his accretive habit of composition as that of a mind 'shrewd and muscular in purpose. ${ }^{28}$ Besides, Steffan's attempt to read every example of revision as progress 'from thinness to density, from dilution to concentration ${ }^{29}$ serves to reinstate authorial intention in the guise of skilled craftsmanship and reveals an anxiety to establish Byron as a 'serious' poet, an anxiety that might render questionable the editors' impatience with Byron's 'whimsicality.'

The Variorum edition is nevertheless valuable for its discernment of patterns of composition, its generous quotations from correspondence between Byron, Murray, and Hobhouse that details the interaction between publisher and poet and between poet and audience, its list of expurgations and revisions, its charting of Mary Shelley's role as amanuensis and her significant emendations to the text, and its sensitive use of Byron's comments, responses and statements of intention and literary principle in the interests of a complex edition that records the process of literary production.

Steffan inadvertently suggests a radical dimension to the problem of authorial intention when he draws attention to the fact that Byron's statements of artistic purpose were contingent upon public response to his work. In other words, intention is a recursive process that can be delineated only as effect, not cause. Moreover, genius seems oddly inadequate to the claims of propriety, popular taste, publishing prudence, and sentiment.

The development of Don Juan is a remarkable testimony to Peckham's account of 'policing,' of the exigencies of an author's cultural and semiotic situation. Byron's politics were often the consequence of personal affronts. He made numerous concessions to propriety by deleting expletives and explicit sexual and scatological detail; he desired to remain anonymous for fear of losing his daughter in a law suit; he removed his dedication to Southey, his stanzas on Castlereagh, Brougham, and Romilly, and his prose preface to Wordsworth; he delegated the responsibility of producing fair copies to Mary Shelley and thus came to revise his cantos less and less; he even progressively reduced the number of personal pronouns in the poem to accord with his expurgation of autobiographical detail.

How then is one to reconcile the poet who wished to publish under the aegis of anonymity with the poet who could not keep himself out of his writing? If one refrains from making the narrative voice in the poem syn- 
onymous with Byron's, does not the wealth of textual evidence paradoxically suggest the opposite? Even if Byron is invisible, he is everywhere felt (if I may paraphrase James Joyce's comment on the narrative voice in Dubliners). Consequently, despite the apparent focus on empirical evidence, the editor / textual critic returns surreptitiously to origins, to, once again, the recording of an authorial voice, albeit subject to contradictions and historical revision.

The value of an editorial process that is sensitive to the authorial self as the site of 'the painful rifts of difference creative of culture ${ }^{\prime 30}$ lies in its rendering the 'language of hagiology' impossible - what is retrieved is no longer an authorial monad but a 'complex assembly of interests and factions $^{\prime 31}$ that is neither determined nor determining. In short, both author and text become the sites of possibility rather than of authority.

McGann is interested in states of text rather than in states of mental turbulence. As he asserts in his editorial introduction, all major editions of Byron's poetry are textually corrupt because of faulty transcription, failure to correct errors which first appeared in the I832-33 Moore-Wright edition (the Variorum copy-text), and failure to use Byron's corrected proofs for Cantos I-4 of Don Juan. The case for a new edition of Byron's works is made here in relentlessly textual terms - graphic evidence of textual authority is the only one that counts, apparently. The aim of McGann's edition, therefore, is to 'establish a complete collection of Byron's poetical works, and to reproduce a correct text of those works. ${ }^{32}$

McGann presents the poems in chronological sequence, a method he shares with the Variorum editors. However, the latter's chronology is often confused with the development of a thematic focus and obscures the temporal development of poetic talent. Liu advocates this method, and temporal sequence is certainly the basis of the argument surrounding the copytext for Jack Stillinger's edition of Keats.

The choice of copy-text depends on the textual relevance of manuscripts and editions. The criteria of textual relevance stem from editions authorised by Byron (those issued by Murray), manuscripts written and corrected by Byron or used as copy-text for an edition authorised by Byron, and editions that have gained currency such as Coleridge's and More's. The incorporation of notes or of contextual research does not constitute a critical edition for McGann - it must attempt to establish a correct text. In his edition of Keats's poems, Stillinger attempts to establish a text that would, ideally, meet with authorial approval. While McGann appears to disregard the question of the author in his focus on textual relevance, the criteria for relevance stem from authorial sanction. The availability of corrected proofs strengthens his case, of course. This reliance on Byron's authority becomes evident in his choice of later editions of works as copy-texts 
before I 8 I 6 and early editions as copy-texts when Byron shifted residence to the Continent. Byron's accretive habit makes McGann's choice a reasonable one.

Byron was a careful corrector of erroneous punctuation, but never developed a system and relied on William Gifford for consistency in such matters. Bowers's contention that editors should adhere to the accidentals of manuscripts becomes tenuous at best in the collaborative exercise that became Don Juan. Moreover, Tanselle's distinction between documents intended for publication and those intended for private use becomes a very complicated problem in the case of Byron - private and public are not readily distinguishable, and while Byron intended what he wrote to be published, he was often persuaded or forced to do otherwise.

Even so stern a guardian of textual authority as McGann is called upon to exercise editorial discretion when punctuation in the copy-text is 'clearly inadequate to carry the sense of the verse ${ }^{\prime 33}$ and when substantive variants are clearly the result of misprinting or editorial misjudgement. McGann is less arbitrary in relation to orthography. He retains the past participial form because Byron's manuscripts display a sensitivity to metrical difference, a practice that wins him Drummond Bone's approval. ${ }^{34}$ McGann adopts the curious (for reasons I shall explain) policy of deferring to substantive readings that have acquired 'normative' status. ${ }^{35}$

Most reviewers of McGann's edition endorse his claims for a definitive text, partly because of the wealth of material at his disposal and his expansion and authentication of the Byron corpus. More significantly, perhaps, reviewers seem to believe he has succeeded in conducting a process of editing 'which [does not] call attention to itself' ${ }^{36}$ and which remains the servant of the text. Reiman and Stillinger believe there are important gaps between process and product and that the claim to definitiveness should be examined with care.

Reiman comments on the inconsistency which allows McGann to make claims on behalf of normative texts even though he has impugned their textual accuracy. ${ }^{37}$ The problem seems to me to lie with the concern to reproduce the historical reality of the text that Reiman himself advocates elsewhere. McGann proves oddly conservative in this regard because history has conferred on the text in question a certain status. Moreover, the editor proves far more visible than he would like because the volumes often fail to distinguish between Byron's notes and McGann's, and present silent emendations that Reiman sees as equivalent to correcting the history of Shakespeare and the geography of Homer.

Stillinger makes the more serious objection, questioning, ironically enough, the reliability of McGann's own text. Bone points out errors in the 
early volumes, but Stillinger focuses on the principles involved. Often, McGann uses posthumous printings as copy-texts; they should 'never have independent authority when their sources are extant. ${ }^{38}$ Besides, McGann is selective about the variants he cites without offering bases for the omission of certain 'standard' texts and Stillinger seems decidedly uneasy about 'clear' misprints, because they often contribute to plausible readings. All reviewers point to the actual difficulty of consulting these volumes in the absence of editorial assistance (in all but the first volume) and of cross-references. Some of the complaints have been addressed in later volumes.

There are, as no one would deny, real gains in the McGann edition over the Steffan-Pratt Variorum. The draft Preface finds a place amidst the unincorporated and rejected stanzas because Byron replaced it with the Dedication. It does not head the poem as it does in the Variorum edition. Moreover, the recovery of corrected proofs has revised the text of the first two cantos, and brought to light alternative versions of the stanza on Castlereagh between which Byron apparently never decided. So much for definitive texts! McGann's choice is made on the basis of which stanza is better poetry - a provisional solution if there ever was one. The proofs also demonstrate the active collaboration between Hobhouse and Byron to produce authorial intention. The original epigraph read 'Domestica Facta.' Hobhouse added a question mark at the end of I.ix.ii, a change to which Byron agreed but which never appeared in the received poem. Hobhouse's changes reflected his objection to indelicacy and merited a witty retort from Byron:

I doubt if laureate and Iscariot are good rhymes, but must say, as Ben Jonson said to Sylvester, who challenged him to rhyme with 'I, John Sylvester, lay with your sister.' Jonson answered, 'I, Ben Jonson, lay with your wife.' Sylvester answered, 'That is not rhyme.' 'No,' said Ben Jonson, 'But it is true.'

Byron's anecdote also lends credence to his interest in literary principle and to his awareness of the subversiveness of his style. As Steffan argues, the annals of his poetic composition are symptomatic of a simultaneous flouting of and reliance on convention.

As a concluding gesture which testifies to the textual editor's 'open' situation, I should like to indicate, in provisional terms, a significant example of textual irrelevance in both editions. The editors of both versions of Don Juan pay brief attention to Mary Shelley's role as amanuensis and to Byron's apparent acquiescence to her significant changes to his text. The editors record these changes but dismiss them as copy errors or as 
lacking the authority of Byron's explicit approval. Mary Shelley's role obviously exceeded that of copyist, yet both editors wish to minimise the importance of her contribution to the active collaboration of men.

I do not wish to be deemed guilty of 'the vanity of superior hindsight,' of extrapolating her importance to a feminist 'canon' to suit my editorial purposes. I merely wish to suggest the possibility that the choice of 'significant context ${ }^{\prime 39}$ determines the postulation of textual relevance. McGann laments the loss of her fair copies of the later cantos, a loss which makes Byron's text indistinguishable from hers, in a sense, and renders authorial sanction impossible. McGann does not deploy this discovery of loss in the interests of retrieving a significantly undecidable rather than a definitive text. As for Steffan, his investment in Byron's display of poetic muscle produces his impatience with the 'sensuous inflation' ${ }^{40}$ of Byron's language and his dismissal of Mary Shelley's changes as egregious errors and concessions to feminine delicacy.

McGann does mention her tendency to dephysicalize Byron's language, but does not let that insight affect his editorial procedure. In Cantos VI-VIII, a consistent pattern begins to emerge where possessives are transformed into neutral definite articles, where sexualized personification is humanized and where sexual difference loses its sharp contours. For example, in 6.67.5, the 'heaved breast' of Sorrow becomes 'heart,' in 6.92.8 she refused to write 'whores,' and in 8.II3.7 'your Houri' becomes 'the young houri' in her transcript. I do not wish to deny that she made errors (Byron corrected many, after all); rather, my attempt is to create room for an alternate interpretation because Steffan also remarks that these 'errors' were habitual.

Byron's letters are full of his resentment of his wife, his sexual jealousy, his desire to destroy the empire of sentiment over which women rule, his preoccupation with female chastity, his anger that women had been issued an eleventh commandment of sorts to refrain from reading his poem /and his surprise that they chose to obey it), and finally, his anxiety over the impending loss of his daughters.

In the face of such textual evidence of the relevance of sexual difference to Byron's cultural and semiotic situation, why do editors fail to grant his amanuensis and unauthorized editor due consideration? In short, if poet and editor attempt to represent 'the painful rifts of difference creative of culture,' the registering of sexual difference in the course of poetic composition might complicate the interpretation of poetic self and of the corpus it produces.

NOTES

I Byron's Don Juan, eds. T.G. Steffan and W.W. Pratt, 4 vols. (Austin: University of 
Texas Press, 1957). Quotations are from these volumes, hereafter abbreviated as Variorum.

2 Lord Byron: The Complete Poetical Works, ed. Jerome J. McGann, 5 vols. (Oxford: The Clarendon Press, I980-86). Quotations are from these volumes, hereafter abbreviated as $C P W$.

3 The Scarlet Letter in The Works of Nathaniel Hawthorne, ed. Fredson Bowers (Columbus: Ohio University Press, 1962), p. I.

4 I am discussing Bowers's contentions as symptomatic of a certain version of editorial procedure. See Fredson Bowers, 'Mixed Texts and Multiple Authority, Text 3 (I987): 63-90, for a more up-to-date example of his thinking.

5 See G. Thomas Tanselle, 'Greg's Theory of Copy-Text and the Editing of American Literature,' Studies in Bibliography 28 (I975):167-229, and 'The Editing of Historical Documents,' Studies in Bibliography 3 I (I978): I-56 for details.

6 Morse Peckham, 'Reflections on the Foundations of Modern Textual Editing,' Proof I (I97I): I 22-55.

7 Ibid., p. I36.

8 Ibid., p. 145 .

9 Ibid., p. I55.

IO Ibid., p. I3 I.

I I Ibid., p. I43.

I2 Alan Liu, review of Wordsworth's Historical Imagination: The Poetry of Displacement, by David Simpson, The Wordsworth Circle I9, 4 (Autumn I988): I73.

I 3 Donald Reiman, 'Romantic Bards and Historical Editors,' Studies in Romanticism 2I (I982): 477 .

I4 Ibid., p. 477.

I5 Ibid., p. 492.

I6 Jerome J. McGann, A Critique of Modern Textual Criticism /Chicago and London: University of Chicago Press, I9831, p. 48.

17 Variorum I: vii.

18 Ibid., p. ix.

I9 Reiman, p. 492.

20 Ibid.

2 I Ibid., p. 480 .

22 Variorum, 2: xv.

23 Ibid., p. xiv.

24 Ibid., p. xvi.

25 Ibid., p. viii.

26 Ibid., p. vii.

27 Ibid., I: I 29.

28 Ibid., p. I8I.

29 Ibid., p. I32. 
30 Liu, p. I73.

3 I David Simpson, as quoted by Liu, p. I78.

$32 C P W, \mathrm{I}: \mathrm{xxviii}$.

33 Ibid., p. xxxvii.

34 Drummond J. Bone, review of Lord Byron: The Complete Poetical Works, ed. Jerome J. McGann, Modern Language Review 78 (Jan. I 983): I 54-57.

$35 C P W, \mathrm{I}: \mathrm{xI}$.

36 Jerome J. McGann, 'Editing Byron's Poetry,' Byron Journal I (I 973): 5.

37 Donald Reiman, review of Lord Byron: The Complete Poetical Works, I-3, ed. Jerome J. McGann, The Keats Shelley Memorial Bulletin 34 (I983): 66-73.

38 Jack Stillinger, review of Lord Byron: The Complete Poetical Works, I-3, ed. Jerome J. McGann, Journal of English and Germanic Philology 8 I (Jan. I982): I 27. 39 Liu, p. 175.

40 Variorum, I: 123. 